\title{
A visual literacy course for dermatology trainees
}

DOI:

10.1111/bjd.15073

\section{Document Version}

Accepted author manuscript

Link to publication record in Manchester Research Explorer

\section{Citation for published version (APA):}

Griffin, L. L., Chiang, N. Y. Z., Tomlin, H., Young, H. S., \& Griffiths, C. E. M. (2016). A visual literacy course for dermatology trainees. The British journal of dermatology. https://doi.org/10.1111/bjd.15073

\section{Published in:}

The British journal of dermatology

\section{Citing this paper}

Please note that where the full-text provided on Manchester Research Explorer is the Author Accepted Manuscript or Proof version this may differ from the final Published version. If citing, it is advised that you check and use the publisher's definitive version.

\section{General rights}

Copyright and moral rights for the publications made accessible in the Research Explorer are retained by the authors and/or other copyright owners and it is a condition of accessing publications that users recognise and abide by the legal requirements associated with these rights.

\section{Takedown policy}

If you believe that this document breaches copyright please refer to the University of Manchester's Takedown Procedures [http://man.ac.uk/04Y6Bo] or contact uml.scholarlycommunications@manchester.ac.uk providing relevant details, so we can investigate your claim.

\section{OPEN ACCESS}


Received Date : 27-Jul-2016

Revised Date : 28-Aug-2016

Accepted Date : 14-Sep-2016

Article type : Research Letter

\section{A visual literacy course for dermatology trainees}

L.L. Griffin, N.Y.Z. Chiang, H. Tomlin, H.S. Young, C.E.M. Griffiths

Dermatology Centre, Salford Royal NHS Foundation Trust, University of Manchester, Manchester Academic Health Science Centre, Manchester, UK

\section{Correspondence}

Professor CEM Griffiths

Email: christopher.griffiths@manchester.ac.uk

Funding sources: None

\section{Conflicts of interest}

None declared.

This article has been accepted for publication and undergone full peer review but has not been through the copyediting, typesetting, pagination and proofreading process, which may lead to differences between this version and the Version of Record. Please cite this article as doi: 10.1111/bjd.15073

This article is protected by copyright. All rights reserved. 
Dear Editor,

First described by John Debes $^{1}$ in 1968 , visual literacy (VL) refers to the ability of an observer to derive meaning from images. ${ }^{2}$ In addition to understanding the image itself, the wider meaning is considered and deeper critical thinking encouraged., ${ }^{1,3}$

In contrast with other medical specialties, the interpretation of visual signs and gross pathology remains key to dermatological practice. ${ }^{4}$ Diagnostic accuracy may be increased by careful observation without preconceptions. ${ }^{4}$ Thus, description of lesions in dermatological practice may be considered as "the expression of pathological art". ${ }^{5}$ On this basis we believe dermatologists should have fluent VL skills, which could be developed throughout their training.

Randomised studies in medical schools in the United States have shown significantly improved visual diagnostic skills among course participants through the use of artwork in VL teaching., ${ }^{6,7}$ To our knowledge, no such training has previously been reported in UK dermatology. We developed a pilot course to investigate the benefit of $\mathrm{VL}$ training for trainee dermatologists.

The course, led by an experienced art historian and educator (HT) was conducted for the first time in Autumn 2015. Course participants were eight higher specialty trainees (specialist registrars) in dermatology: four in their final year (ST6); one penultimate year (ST5); two second year (ST4) and one first year (ST3). Participants attended five art gallery based sessions of approximately two hours in duration, with additional self and group reflection following the course. All attendees maintained an art journal to record their experiences. Learning techniques included: analysis of selected artwork; group discussion; short lectures and follow-up resources.

This article is protected by copyright. All rights reserved. 
Participants were exposed to diverse ranges of artwork in small workshops and gallery spaces. These included abstract, landscape, still life, portraiture and figurative artwork. A different piece of artwork was used to demonstrate the focus of each session, including the use of colour, texture, pattern and contrast. Participants were encouraged to challenge their own perceptions and consider the viewpoint of the artist, and to develop their own descriptive style (Figure 1a \& b).

Following anonymised post-course evaluation; all participants rated the course as either excellent $(n=3,37.5 \%)$ or very good $(n=5,62.5 \%)$. Participants also reported subjective improvement in observational skills applicable to dermatology practice (strongly agree $n=2,25 \%$; agree $n=6,75 \%$ ). The majority believed their written and verbal descriptive skills had improved $(n=7,87.5 \%)$. There was less certainty regarding the effect on relationships and interpreting patients' emotional responses, which could be reflective of the timing of feedback collection directly after the last session of the course. Overall, trainees gave positive feedback regarding improvement in their clinical observational and descriptive skills.

A post-course Clinical and Observational Skills Assessment was performed using artwork and clinical images. Due to availability, four course participants and three controls completed the assessment. The control group comprised: one final year specialist registrar; one penultimate year registrar and a senior international clinical fellow. Participants and control subjects were shown photographs of common dermatological conditions and images of paintings not previously seen by the course participants. They were asked to identify key visual features from these images based on the Visual Thinking Strategies (VTS) method ${ }^{8}$, and to comment on texture, lines and contour, colour (or shading) and contrast. Scores were assigned for correct answers, which were pre-set by dermatologists (clinical images) and an arts educator for description of features (artwork). The assessors were blinded regarding course participation. Descriptive statistics were used to analyse the results.

This article is protected by copyright. All rights reserved. 
There was no significant difference in mean +/- standard deviation observations for clinical images (Controls: $12.67+/-3.79$; Participants: $13.25+/-2.50 ; p=0.81$ ) or artwork (Controls: $43.00+/-10.54$, Participants $60.75+/-18.41 ; p=0.2$ ). However, this would be expected due to the small sample sizes and relative under powering of the study.

The VTS teaching method was developed by Housen and Yenawine using artwork to stimulate deeper critical thinking, build relationships and improve VL. ${ }^{3}$ Successful arts education of medical students in the United States has been performed using VTS. ${ }^{6,7}$ Dermatology residents have anecdotally been documented to improve their performance during Grand Rounds following a single session interpreting artwork, but no formal assessment has previously been made of the impact on dermatology practice. $^{9}$

This pilot study was limited by the small sample size. Also, it was not possible to match the course attendees and the control group accurately. Finally, evaluation was performed directly after the last session of the course, which did not allow for longerterm reflection on its impact.

For the first time, dermatology trainees in the UK were exposed to structured VL training, aiming to enhance their descriptive and clinical observational skills. The results of this innovative pilot study are encouraging, and it is hoped further course development may evolve into a national network of specialist VL training for dermatologists. We believe that ongoing collaboration with the arts will enhance dermatology training in years to come.

This article is protected by copyright. All rights reserved. 


\section{References}

1. Bamford A. The Visual Literacy White Paper.: Adobe systems Pty Ltd, Australia.; 2003.

2. Giorgis C, Johnson NJ, Bonomo A, Colbert C, Conner A, Kauffman G, et al. Visual literacy. Reading Teacher. 1999;53:146-53.

3. Housen AC. Aesthetic thought, critical thinking and transfer. Arts and Learning Research Journal. 2002;18:99-132.

4. Jackson R. Importance of being visually literate - observations on art and science of making a morphological diagnosis in dermatology. Archives of Dermatology. 1975;111:632-6.

5. de Souza EM, Ayres Vallarelli AF. Dermatology in the arts. Anais Brasileiros De Dermatologia. 2009;84:556-8.

6. Naghshineh S, Hafler JP, Miller AR, Blanco MA, Lipsitz SR, Dubroff RP, et al. Formal art observation training improves medical students' visual diagnostic skills. Journal of General Internal Medicine. 2008;23:991-7.

7. Dolev JC, Friedlaender LK, Braverman IM. Use of fine art to enhance visual diagnostic skills. Jama-Journal of the American Medical Association. 2001;286:10201.

8. Reilly JM, Ring J, Duke L. Visual thinking strategies: A new role for art in medical education. Family Medicine. 2005;37:250-2.

9. Braverman IM. To see or not to see: How visual training can improve observational skills. Clinics in Dermatology. 2011;29:343-6.

\section{Figure Legends}

Figure 1 (a) Group discussion of David Bomberg's 'Storm Clouds' at Salford Museum and Art Gallery to demonstrate the use of colours in artwork; (b) Detailed study of colours in smaller groups.

This article is protected by copyright. All rights reserved. 

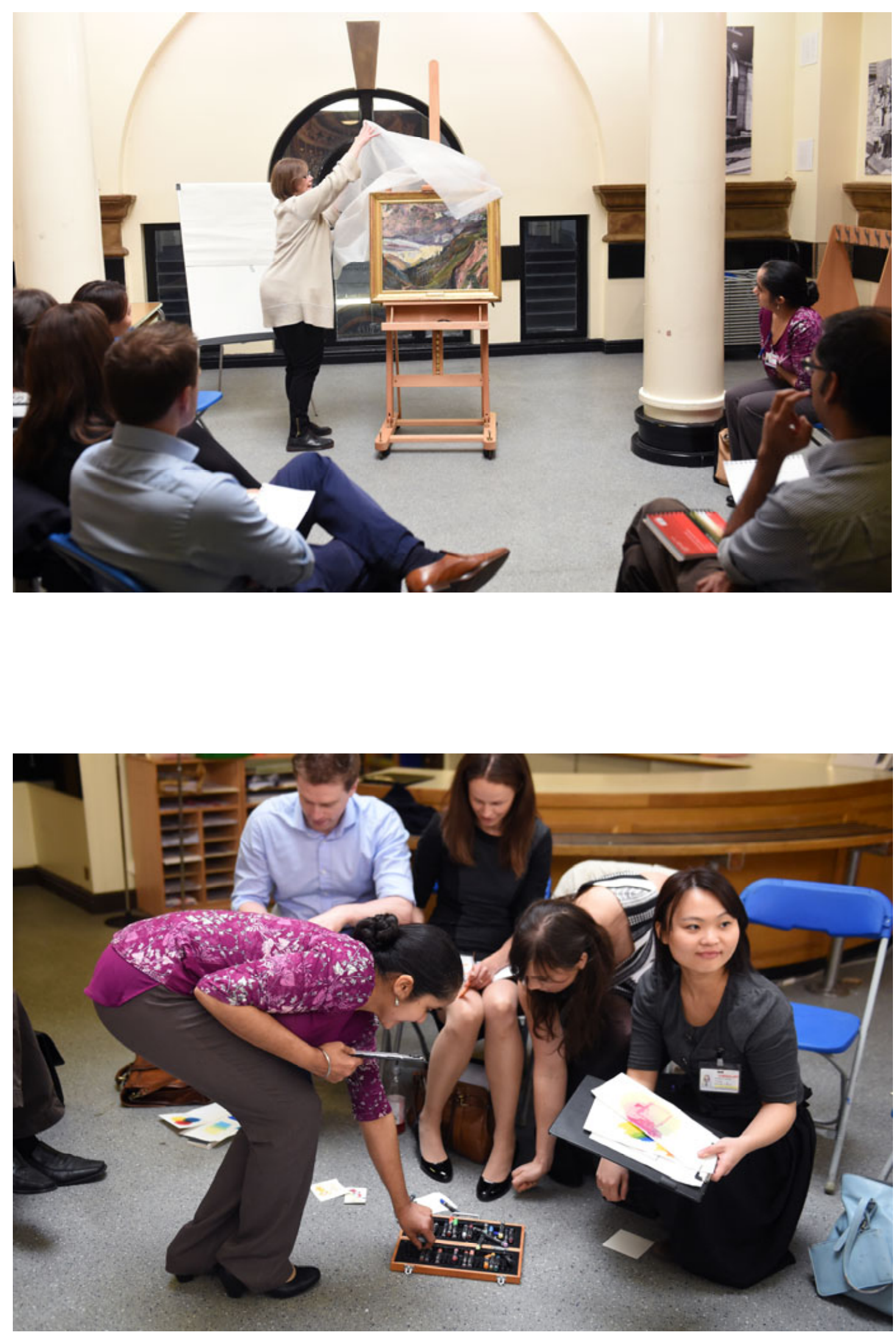

This article is protected by copyright. All rights reserved. 